\title{
Comment on Kanis et al.: "European guidance for the diagnosis and management of osteoporosis in postmenopausal women"
}

\author{
J. O. Clausen
}

Received: 13 November 2008 / Accepted: 2 December 2008 / Published online: 16 December 2008

(C) The Author(s) 2008. This article is published with open access at Springerlink.com

Dear Editors,

Kanis et al. erroneously state in a recent paper about the diagnosis and management of osteoporosis in postmenopausal women that $100 \mu \mathrm{g}$ of $\mathrm{PTH}(1-84)$ is equivalent to $40 \mu \mathrm{g}$ of teriparatide, $\mathrm{PTH}(1-34)$ [1]. This equivalence was calculated from their respective molecular weights $(4,115$ for teriparatide [2], 9,426 for full-length PTH [3]) but does not consider bioavailability. The bioavailability of PTH(1-34) and $\mathrm{PTH}(1-84)$ are $95 \%$ and $55 \%$, respectively $[4,5]$.

Bioequivalence requires that the number of $\mathrm{PTH}(1-34)$ and PTH(1-84) molecules should be the same: $N_{\mathrm{PTH}(1-34)}=N_{\mathrm{PTH}(1-84)}$

The clinical dose is based on molecular weight and bioavailability leading to the equation:

$$
\frac{m_{\mathrm{PTH}(1-34)} \times P_{\mathrm{abs}(1-34)}}{M_{\mathrm{PTH}(1-34)}}=\frac{m_{\mathrm{PTH}(1-84)} \times P_{\mathrm{abs}(1-84)}}{M_{\mathrm{PTH}(1-84)}}
$$

(where $M$ is the molecular weight of PTH, $P_{\text {abs }}$ the bioavailability, and $m$ the mass of PTH).

Using this calculation, $100 \mu \mathrm{g}$ of $\mathrm{PTH}(1-84)$ is equivalent to $25 \mu \mathrm{g}$ of teriparatide $\{100 \mu \mathrm{g} \times(55 / 95) \times 4,115 / 9,426=$
$25 \mu \mathrm{g}$ \} and these are the approximate doses used in the treatment of postmenopausal osteoporosis.

Open Access This article is distributed under the terms of the Creative Commons Attribution Noncommercial License which permits any noncommercial use, distribution, and reproduction in any medium, provided the original author(s) and source are credited.

\section{References}

1. Kanis $J$ et al (2008) European guidance for the diagnosis and management of osteoporosis in postmenopausal women. Osteoporos Int 19:399-428 doi:10.1007/s00198-008-0560-z

2. Zhou $H$ et al (2002) Solid phase synthesis of $N$ terminal 1-34 peptide of human parathyroid hormone. Zhongguo Shenghua Yaowu Zazhi 23:109-111

3. Ishibashi Y et al (1993) Fragmentation of parathyroid hormone, a $9.4 \mathrm{kDa}$ polypeptide, in liquid secondary ion mass spectrometry. Biol Mass Spectrom 22:98-100

4. EPAR (2004) Forsteo scientific discussion. http://www.emea. europa.eu/humandocs/PDFs/EPAR/forsteo/659802en6.pdf

5. EPAR (2006) Preotact scientific discussion. http://www.emea. europa.eu/humandocs/PDFs/EPAR/preotact/H-659-en6.pdf
J. O. Clausen $(\bowtie)$

Medical Scientific Strategy and Medical Marketing, Nycomed,

Langebjerg 1,

4000 Roskilde, Denmark

e-mail: jesper.clausen@nycomed.com 